\title{
LATEST UPDATE OF ODONTOGENIC TUMORS IN ALEXANDRIA UNIVERSITY, EGYPT: A 5-YEAR RETROSPECTIVE STUDY USING WHO 2017 CLASSIFICATION
}

\author{
Marwa G. Noureldin* and Hala R. Ragab**
}

\begin{abstract}
PURPOSE: This retrospective study was intended to assess the frequency and distribution of different types of odontogenic tumors relative to the WHO 2017 latest updates, by reviewing the records of the oral and maxillofacial department, faculty of dentistry in Alexandria throughout a 5 - year period.
\end{abstract}

METHODS: The records related to the years January 2014 till December 2018 at the oral and maxillofacial department of the faculty of dentistry in Alexandria were inspected. The odontogenic tumors were investigated for the frequency, gender, age, site. The data was recorded then analyzed using Microsoft Excel 2016.

RESULTS: Two hundred and fifteen tumors were documented, out of which $26(12.09 \%)$ cases confirmed the diagnosis of odontogenic tumors (OTs). 15 (57.69\%) of the assessed OTs occurred in females while $11(42.31 \%)$ were seen in males. The average age of the patients was 28.65 ranging between 7 and 73 years. Benign odontogenic tumors comprised $23(88.46 \%)$ cases while $3(11.54 \%)$ cases were malignant. $14(53.85 \%)$ of the assessed OTs were located in mandible the while $12(46.15 \%)$ were in the maxilla. The odontoma was found to be the most prevalent OT represented in $9(34.62 \%)$ cases followed by ameloblastoma in $4(15.38 \%)$ cases.

CONCLUSIONS: Differences between our findings and those of previous studies of various populations were witnessed. OTs may greatly diverge according to the version of classification used and by the sample size of the study.

\section{INTRODUCTION}

Odontogenic tumors (OTs) are a varied group of lesions that are specifically seated inside the jaw bones or in the mucosal tissue. OTs have various clinical behavior and histopathologic features.
OTs are originated from ectomesenchymal and/or epithelial tissues that constitute the tooth-forming system. Similar to normal odontogenesis, the OTs represent inductive interfaces between epithelium and odontogenic ectomesenchyme. ${ }^{(1,2)}$

* Lecturer, Department of Oral and Maxillofacial Surgery, Faculty of Dentistry, Alexandria University, Egypt.

** Assistant professor, Department of Oral and Maxillofacial Surgery, Faculty of Dentistry, Alexandria University, Egypt. 
The WHO classification allocated OTs into two major categories; malignant and benign however, the etiology is still unknown. Most of benign OTs seem to occur de novo, while the malignant OTs more often occur from their benign precursor but may start de novo. The 2005 classification systematized benign OTs as 'Odontogenic epithelium with mature, fibrous stroma without odontogenic ectomesenchyme,' 'Odontogenic epithelium with odontogenic ectomesenchyme, with or without hard tissue formation,' and 'Mesenchyme and/ or odontogenic ectomesenchyme with or without odontogenic epithelium'. (3)

Continuous renewal of this dynamic classification was achieved with new entities added, and some older entities eliminated. The WHO 2017 (4th) edition is the final update, announced at the beginning of 2017. (Table 1) OTs are now categorized in a simpler way than 2005 edition as epithelial, mesenchymal and mixed according to the tissue they originated from. Moreover, the 2017 classification presented malignant odontogenic tumor in a simpler form than the detailed and complicated classification of 2005. ${ }^{(4)}$

The purpose of this study was to evaluate the frequency and distribution of several types of OTs relative to the WHO 2017 latest updates, by reviewing the records of the oral and maxillofacial (OMF) surgery department, faculty of dentistry in Alexandria throughout a 5- year period.

\section{MATERIALS AND METHODS}

This retrospective study was executed to evaluate the frequency of occurrence and distribution of OTs in the period from January 2014 till December 2018 at the OMF surgery department of the faculty of

TABLE (1) WHO 2017 classification for benign and malignant odontogenic tumor

\begin{tabular}{|c|c|}
\hline \multicolumn{2}{|c|}{2017 WHO classification } \\
\hline Benign & Malignant \\
\hline Benign epithelial odontogenic tumors & Odontogenic carcinomas \\
\hline Ameloblastoma & Ameloblastic carcinoma \\
\hline Ameloblastoma, unicystic type & Primary intraosseous carcinoma \\
\hline Ameloblastoma, extraosseous/peripheral type & Sclerosing odontogenic carcinoma \\
\hline Metastasizing ameloblastoma & Clear cell odontogenic carcinoma \\
\hline Squamous odontogenic tumor & Ghost cell odontogenic carcinoma \\
\hline Calcifying epithelial odontogenic tumor & Odontogenic carcinosarcoma \\
\hline \multicolumn{2}{|l|}{ Adenomatoid odontogenic tumor } \\
\hline Benign mixed epithelial and mesenchymal odontogenic tumors & Odontogenic sarcomas \\
\hline \multicolumn{2}{|l|}{ Ameloblastic fibroma } \\
\hline \multicolumn{2}{|l|}{ Primordial odontogenic tumor } \\
\hline \multicolumn{2}{|l|}{ Odontoma } \\
\hline \multicolumn{2}{|l|}{ Odontoma, compound type } \\
\hline \multicolumn{2}{|l|}{ Odontoma, complex type } \\
\hline \multicolumn{2}{|l|}{ Dentinogenic ghost cell tumor } \\
\hline \multicolumn{2}{|l|}{ Benign mesenchymal odontogenic tumors } \\
\hline \multicolumn{2}{|l|}{ Odontogenic fibroma } \\
\hline \multicolumn{2}{|l|}{ Odontogenic myxoma/myxofibroma } \\
\hline \multicolumn{2}{|l|}{ Cementoblastoma } \\
\hline Cemento-ossifying fibroma & \\
\hline
\end{tabular}


dentistry in Alexandria, Egypt. This department is the main center of OMF in Alexandria, serving a huge number of patients from Alexandria in addition to patients referred from other nearby cities.

The study was approved by the research ethics committee, Faculty of Dentistry, Alexandria University. Patients' confidentiality was strictly conserved by not revealing patients' name or any potential identifier on the worklist.

Complete medical records with clear, definitive histological diagnosis were enrolled in this study. The histopathological examinations were done by a senior pathologist in the department of oral pathology, Faculty of Dentistry, Alexandria University.

From a sum of 215 tumor records, all necessary data were collected including the frequency, age, gender, site of the neoplasm whether related to the maxilla or the mandible. Tumors were considered as OTs, according to the WHO 2017 classification. ${ }^{(4)}$

The data was recorded then analyzed using Microsoft Excel 2016. Percentage and frequency tables were used to describe the pattern of distribution and the allocation of different OTs according to different age groups, sex and sites.

\section{RESULTS}

\section{Data records}

After exclusion of incomplete medical records and records lacking histopathological reports of biopsy, only 215 records of tumoral diagnosis were complete and were found suitable for this study. From 215 complete medical records of OMF tumors, $26(12.09 \%)$ with the diagnosis of OT were collected.

\section{Pattern of OTs}

Of the 26 cases, the majority were benign accounting for $23(88.46 \%)$, while the remaining 3 $(11.54 \%)$, were malignant tumors. Odontoma (OD) was the most frequent type of benign OT, accounting for 9 (34.62\%) followed by Ameloblastoma (AML) in $4(15.38 \%)$ of the cases. However, Ameloblastic carcinoma (AC) was the only type of malignant OT diagnosed (Table 2).

TABLE (2) Frequency distribution of OTs at OMFS department, Faculty of dentistry, Alexandria University

\begin{tabular}{clcc}
\hline \multirow{2}{*}{$\begin{array}{c}\text { Benign } \\
\text { tumors }\end{array}$} & \multicolumn{1}{c}{ Type of OT } & Number & percentage \\
\cline { 2 - 4 } & Adontoma & 9 & $34.62 \%$ \\
\cline { 2 - 4 } & Ameloblastoma & 4 & $15.38 \%$ \\
\cline { 2 - 4 } & $\begin{array}{l}\text { Cemento-ossifying } \\
\text { fibroma }\end{array}$ & 3 & $11.54 \%$ \\
\cline { 2 - 4 } & Odontogenic myxoma & 2 & $7.69 \%$ \\
\cline { 2 - 4 } & Odontogenic fibroma & 2 & $7.69 \%$ \\
\cline { 2 - 4 } & Ameloblastic fibroma & 2 & $7.69 \%$ \\
\cline { 2 - 4 } & AOT & 1 & $3.85 \%$ \\
\hline Malignant & Ameloblastic & 3 & $11.54 \%$ \\
\hline tumors & Carcinoma & & \\
\hline \multirow{2}{*}{ Total } & & 26 & $100.00 \%$ \\
\hline
\end{tabular}

\section{Allocation of $O T$ cases in relation to sex}

From the 26 OT cases, 15 (57.69\%) were females, while the remaining $11(42.31 \%)$ were males. Cemento-ossifying fibroma (COF) and odontogenic myxoma were the two exclusively diagnosed OTs among females. Odontoma was more commonly diagnosed among the male patients with male to female sex ratio of 1.25:1. However, AML, odontogenic fibroma and ameloblastic fibroma had equal distribution among both sexes (Table 3 ).

\section{Allocation of $O T$ cases in relation to age}

The age of patients ranged from 7 to 73 years with average age of 34 years. The distribution according to age was, $10(38.46 \%)$ patients within the age group of $0-19$ years, 9 (34.62\%) patients within the age group of 20-39 years. 7 (26.92\%) patients within the age group of $>=40$ years. 
TABLE (3) Distribution of OTs by sex at OMFS department, Faculty of dentistry, Alexandria University

\begin{tabular}{lcc}
\hline Type of OT & Female & Male \\
\hline Odontoma & 4 & 5 \\
\hline Ameloblastoma & 2 & 2 \\
\hline Cemento-ossifying fibroma & 3 & 0 \\
\hline Ameloblastic Carcinoma & 1 & 2 \\
\hline Odontogenic myxoma & 2 & 0 \\
\hline Odontogenic fibroma & 1 & 1 \\
\hline Ameloblastic fibroma & 1 & 1 \\
\hline AOT & 1 & 0 \\
\hline Total & 15 & 11 \\
\hline Percentage & $57.69 \%$ & $42.31 \%$ \\
\hline
\end{tabular}

ODs were commonly seen among the age group of 0-19 and 20- 39 years which accounted $5(55.6 \%), 4(44.4 \%)$. AML cases were commonly seen in the age group of $>=40$ years which accounted $3(75 \%)$. Odontogenic myxoma, odontogenic fibroma and ameloblastic fibroma were equally seen among the age groups of 0-19 and 20- 39 years. Also, COF showed equal distribution between the 3 age groups. The single case of Adenomatoid odontogenic tumor (AOT) was seen in the age group of $>=40$ years. AC was seen in patients age group of 0-19 and >=40years which accounted 1(33.3), 2 $(66.7 \%)$. (Table 4).

\section{Allocation of OT case in relation to location}

The mandible was more involved than the maxilla comprising 14(53.85\%).and 12(46.15\%) cases respectively. Of the different classes of OTs, ODs were predominantly seen in the maxilla which accounted for $6(66.67 \%)$ in which the compound OD was exclusively seen in the maxilla. AML was most frequently seen in the mandible which accounted 3 (75\%). Similarly, COF was more frequent in the maxilla which accounted $2(66.67 \%)$.
$\mathrm{AC}$ and odontogenic myxoma were exclusively seen in the mandible, while AOT was exclusive to the maxilla. Odontogenic fibroma and ameloblastic fibroma equally affected both jaws. (Table 5).

TABLE (4) Distribution of OTs by age at OMFS department, Faculty of dentistry, Alexandria University

\begin{tabular}{cccc}
\hline Type of OT & $\mathbf{0 - 1 9}$ & $\mathbf{2 0 - 3 9}$ & $\mathbf{> = 4 0}$ \\
\hline Odontoma & 5 & 4 & 0 \\
\hline Ameloblastoma & 0 & 1 & 3 \\
\hline $\begin{array}{c}\text { Cemento-ossifying } \\
\text { fibroma }\end{array}$ & 1 & 1 & 1 \\
\hline $\begin{array}{c}\text { Ameloblastic } \\
\text { Carcinoma }\end{array}$ & 1 & 0 & 2 \\
\hline $\begin{array}{c}\text { Odontogenic myxoma } \\
\text { Odontogenic fibroma }\end{array}$ & 1 & 1 & 0 \\
\hline Ameloblastic fibroma & 1 & 1 & 0 \\
\hline AOT & 0 & 0 & 1 \\
\hline Total & 10 & 9 & 7 \\
\hline Percentage & $38.46 \%$ & $34.62 \%$ & $26.92 \%$ \\
\hline
\end{tabular}

TABLE (5) Distribution of OTs by location at OMFS department, Faculty of dentistry, Alexandria University

\begin{tabular}{lll}
\hline Type of OT & Maxilla & Mandible \\
\hline Odontoma & 6 & 3 \\
\hline Ameloblastoma & 1 & 3 \\
\hline Cemento-ossifying fibroma & 2 & 1 \\
\hline Ameloblastic Carcinoma & 0 & 3 \\
\hline Odontogenic myxoma & 0 & 2 \\
\hline Odontogenic fibroma & 1 & 1 \\
\hline Ameloblastic fibroma & 1 & 1 \\
\hline AOT & 1 & 0 \\
\hline Total & 12 & 14 \\
\hline Percentage & $46.15 \%$ & $53.85 \%$ \\
\hline
\end{tabular}




\section{DISCUSSION}

In large numbered studies of OTs which have been performed on diverse regions, the age and sex of the patients, the location of the OT lesions were described, and local variations were witnessed. $(5,6)$ However, the frequency of OTs in numerous populations is challenging to compare due to the use of variable classification methods besides, the exclusion of some recently recognized entities. ${ }^{(7)}$

The mainstream of articles which were published after 2005 have used the 2005 WHO classification. ${ }^{(5,7-15)}$ except for only one article in India which used the latest 2017 classification. ${ }^{(16)}$ Therefore, in this study, we aimed at investigating the pattern of OTs according to the up-to-date World Health Organization (WHO) classification 2017. The records over a period of 5 years related to the years 2014 till 2018 at the OMF department of the faculty of dentistry in Alexandria were inspected.

Generally, OTs reports in African populations were found to be limited. ${ }^{(17)}$ To our knowledge, only one study regarding OTs in Dakahliah, Egypt was found. ${ }^{\left({ }^{8}\right)}$

In relation to previous studies using the older classifications, our results showed an increase in the mean value of OTs (12.09\%) amongst OMF tumors. This was in agreement with Ahire et al who used the WHO 2017 classification ${ }^{(16)}$, where the relative occurrence of OTs was $7.14 \%$ in comparison to $5.78 \%$ by Varkhede et al ${ }^{(10)}$ who used an earlier classification. Moreover, the higher value of OTs in our study may be linked to the fact that OTs were represented as a percentage of the tumors of the OMF tumors only, while, many other studies represented the OTs as a percentage of OMF lesions (which also included cystic lesions).

In this study, the relative occurrence of OT $(12.09 \%)$ is considered to be high since OTs are relatively more prevalent in Africans. On the other hand, many non-African studies have claimed that
OTs are a relative rare group of lesions, African studies appear to disprove this opinion. ${ }^{(18)}$ In Brazil, Fernandes et al ${ }^{(19)}$, stated relative occurrences of OTs to be $1.78 \%$. Moreover, in California, Buchner et al ${ }^{(5)}$ and in Mexico, Mosqueda-Taylor et al ${ }^{(20)}$ the occurrences were $1.2 \%$ and $2.5 \%$ respectively. Whereas, in Zimbabwe, Chidzonga et al (21), in Lagos, Ladeinde et al ${ }^{(22)}$, in Libya, Goteti ${ }^{(23)}$, in Kaduna, Adebayo et al ${ }^{(24)}$ and in Nigeria, Lawal AO (18) described the occurrences of $8.6 \%, 9.6 \%, 12.6 \%$, $32 \%$ and $41 \%$ respectively. This inconsistency in frequency rates of OTs are most likely due to inherent regional variation among Africans. ${ }^{(18)}$

In this study, $88.46 \%$ and $11.54 \%$ of tumors were benign and malignant, respectively. The percentage of malignancy was higher than the previous Egyptian study by Tawfik and Zyada $(3.7 \%) .{ }^{(8)}$ However, it was in agreement with other many reports. ${ }^{(8,14,15,17,18,25-27)}$ Male patients were more affected by AC in our study (66.67\%) which was similar to W. Jing et al. study. ${ }^{(25)}$ All 3 cases of $\mathrm{AC}$ in this study were exclusive to the mandible, in disagreement with Sriram study in which the maxilla was more involved $(57.1 \%){ }^{(9)}$

The average age of OTs was 28.65 years with a broad range of (7-73), similar to a previous study by Tawfik and Zyada ${ }^{(8)}$ in Egypt in which the average age was 29.57 with a range of (4-80). Similarly, studies from India, ${ }^{(9)}$ China, ${ }^{(6,25)}$ and Africa. ${ }^{(22)}$ have shown the average age to be peak at the 3rd decade while in Chile ${ }^{(28)}$ and Brazil (19) the mean age was less than a decade. The reason may be related to racial variation.

Overall, a more tendency towards females (57.69\%) was noticed in this study, corroborating the studies of Resquetti Luppi ${ }^{(29)}$, Avelar, Antunes, Santos, Andrade, and Dourado ${ }^{(13)}$ and Osterne et $\mathrm{al}^{(30)}$, which were all Brazilian. Also, agreeing with Regezi et al. ${ }^{(31)}$ and $\mathrm{Wu}$ and Chan. ${ }^{(32)}$ However, Odukoya reported male predilection. ${ }^{(26)}$ In Iran, Taghavi et al. ${ }^{(33)}$ stated that, OTs had a 
slight favoring for men. Equal sex distribution of OTs were recorded by studies from China, ${ }^{(6,25)}$ Australia, ${ }^{(34)}$ and India ${ }^{(9,35)}$. This possibly discloses a gender difference among different populations.

The percentage of OTs in the mandible $(53.85 \%)$ was slightly higher than the maxilla $(46.15 \%)$. This was concurrent with American studies ${ }^{(20,28,31)}$ that showed a nearly matching preference for both jaws. The reason may be attributed to the lower incidence of AML in this study. However, the mandible was the most commonly affected according to studies from Africa ${ }^{(22)}$ and Asia. ${ }^{(6,35)}$

In this study, it should be observed that OD (34.62\%) was the most common odontogenic tumor followed by AML (15.38\%) which was surprisingly in contrast with previous studies from Africa and Asia which reported AML to be the most prevalent OT. ${ }^{(36)}$ Tawfik and Zyada ${ }^{(8)}$ from Egypt reported AML as the most prevalent tumor (41.5\%) while OD being third (13.4\%), Ladeinde de et al ${ }^{(22)}$, Adebayo et $\mathrm{al}^{(24)}$ and Chidzonga et al, ${ }^{(21)}$ all in Africa, reported that AML represented, $63 \%, 73 \%$ and $79.1 \%$, of OTs respectively, while studies from Asia, Young Lu et $\mathrm{al}^{\left({ }^{(6)}\right.}$ and Okada et al ${ }^{(12)}$ showed that AML accounted $58.6 \%$ and $68.9 \%$ of OTs respectively. Comparing this result to the previous literature, relatively low incidence rate of AML was shown and this variance might be attributable to different sampling size of the presented study.

Unexpectedly, our study was in conformity with American studies that which stated that ODs are the commonest OT. In California, USA, Buchner et al ${ }^{(6,5)}$, in Mexico, Mosqueda-Taylor et al ${ }^{(20)}$, in Chile, Ochsenius et al ${ }^{(28)}$, all found ODs to be the most prevalent OT (representing 75.9\%, 34.6\% and $44.7 \%$ respectively). However, in Brazil, Fernandes et $\mathrm{al}^{(19)}$ found in that AML was the most predominant OT comprising $45.2 \%$ of their cases.

The high occurrence of OD observed in this study may be accredited to self-awareness which has increased in the Egyptian population. Also, many odontomas occurred in young age and were accompanied by their parents, who were willingly accepting the histological testing for confirming the benign diagnosis. This agreed with Fregnani et al ${ }^{(37)}$ who argued that differences in OD results might be because of data sources, rather than geography.

There is still an argument among the studies about gender predilection of ODs. While some confirmed a greater incidence in females, $(5,38)$ others claimed in males. ${ }^{(39,40)}$ The third group of studies reports showed no dissimilarity among males and females. ${ }^{(41-43)}$ According to this study, the incidence was found as $55.56 \%$ on behalf of males.

ODs occurred mostly in younger individuals in the first and second decades agreeing with Wright JM and Soluk ${ }^{(44)}$. Some studies have also reported an existence of a correlation between age and type of ODs stating that compound lesions are apparently more frequent in younger patients. ${ }^{(43)}$ Our results coincide with this aspect with a average age of (9.67) for compound ODs and (22.83) for complex ODs.

According to many researchers, the most common site for compound ODs is the anterior maxilla. Complex ODs were reported as prevalent mandibular region posteriorly. ${ }^{(39,45-47)}$ In general, the literature indicates that the frequency of ODs was higher in maxilla than in the mandible, this concurred with our study with frequency of (66.67\%) and (33.33\%) in the maxilla and the mandible respectively. In relation to the result of this study, all compound ODs were located in the maxilla, with $66.67 \%$ in the maxilla anteriorly. This was concurrent with other reports in previous literature. We also found $50 \%$ of complex ODs were in the posterior portion of mandible, $33.33 \%$ in the posterior maxilla and $16.67 \%$ in anterior maxilla. This result also agrees with the literature's higher frequency complex ODs in the mandiblular posterior region.

AML was found to be the second prevalent OT, favoring the mandible in $75 \%$ of the cases. These results concurred with Osterne et al, (30) Taghavi 
et al, ${ }^{(33)}$ Avelar et al, ${ }^{(13)}$ Olgac et al. ${ }^{(11)}$ Also, the AML did not show preference for gender agreeing with Avelar et al. ${ }^{(13)}$

Specifically, in relation to AML, the average age does present significant difference among countries. An extensive review of 3,677 cases of AML by Reichart et al. ${ }^{(48)}$ stated the average age at in developed countries to be 39.1 years in comparison to 27.7 years in developing ones. Our results showed that the average age for AML was (50.5). which is much higher than that reported by Reichart et al. for developed countries, showing that there might be other factors involved. Also, this variation may be related to the smaller size of sample involved in the presented study.

In this study, 3 (11.54\%) patients with COF were reported which exclusively affected females. This was concurrent with the marked predilection for female patients observed by Eversole et al. (49) while it disagreed with Ahire et al ${ }^{(16)}$ in which, almost equal affection among males and females was observed, with a ratio of $0.8: 1$. The maxilla was more involved than the mandible with a ratio of $2: 1$. This was in disagreement with Eversole et al. ${ }^{(49)}$ Also, disagreeing with Ahire et al ${ }^{(16)}$ where maxilla and mandible were equally involved with a ratio of 1.25:1. The smaller sample size might be the cause for the difference in this study.

Odontogenic myxoma included $7.69 \%$ of OTs in our study. Similarly, previous reports showed near frequency. ${ }^{(8,19,22,23,25,50)}$ The tumor was found to prefer the mandible alike reports by Nigerian series, $(22,26)$ but other reports have recorded predilection for maxilla. (11,20,28) Most reports suggest that odontogenic myxoma showed prevalence in female which agrees with our study in which the 2 cases recorded were exclusively seen in females. ${ }^{(9,25,51)}$ However, in California USA and Libya, odontogenic myxoma was predominant in males $(5: 1) .{ }^{(5,23)}$

Odontogenic fibroma is a rare OT, relatively common in females and the incidence peak is between second to fourth decades of life. (52,53)
In this study, odontogenic fibroma constituted $7.69 \%$ of OTs, no sex predilection, equal occurence in maxilla and mandible were observed. These contradicted studies referring to the common occurrence in females.

Ameloblastic fibroma formed $7.69 \%$ of OTs, which was higher than reports from Libya (2.3\%) (23) and other series, ${ }^{(11,19,20,22,24-27,36,50)}$ yet lower than that of an Estonian study (16\%). ${ }^{(54)}$

The least common tumor in this study was AOT comprising only one case (3.85\%). It represented a lesser frequency than that reported in India ${ }^{(16)}$ with a frequency of $16 \%$. The female predilection of AOT was also reported by earlier reports was concurring with our study. (53,55-57) Almost all AOTs showed predilection for the maxilla and the jaws anteriorly, unlike other OTs. ${ }^{(58-60)}$

\section{CONCLUSION}

In general, this analysis revealed some similarities and several variances between our findings and those of previous studies of populations in Africa, Asia, and the Americas. Although OTs may greatly differ in attribution to the version of classification used, they are also influenced by the study sample size. OTs differs according to genetic and/or environmental (epigenetic) factors. Additional investigations are also needed to understand the incidence of OTs in different regions of Egypt.

\section{REFERENCES}

1. Emil AA, Kwasi NI, Kwasi GR: Jaw Tumours in Ghanaian Children and Adolescents - A Retrospective Study. World J Surg Med Radiat Oncol 1: 17, 2012.

2. Akram S, Naghma N, Ali MA, Shakir MM: Prevalence of Odontogenic Cysts and Tumors in Karachi, Pakistan. J Dow Uni Health Sci 7: 20, 2013.

3. El-Naggar, Chan JKC, Grandis JR, Takata T, Slootweg P, editors. WHO classification of Head and Neck Tumours. Chapter 8: Odontogenic and maxilofacial bone tumours. 4th ed. p.205-260, IARC: Lyon; 2017. 
4. Wright JM, Vered M: Update from the 4th Edition of the World Health Organization Classification of Head and Neck Tumours: Odontogenic and Maxillofacial Bone Tumors. Head Neck Pathol 11: 68, 2017.

5. Buchner A, Merrell PW, Carpenter WM: Relative frequency of peripheral odontogenic tumors: a study of 45 new cases and comparison with studies from the literature. J Oral Pathol Med Off Publ Int Assoc Oral Pathol Am Acad Oral Pathol 35: 385, 2006.

6. Lu Y, Xuan M, Takata T, Wang C, He Z, Zhou Z, Mock D, Nikai H: Odontogenic tumors. A demographic study of 759 cases in a Chinese population. Oral Surg Oral Med Oral Pathol Oral Radiol Endod 86: 707, 1998.

7. Gaitán-Cepeda LA, Quezada-Rivera D, Tenorio-Rocha F, Leyva-Huerta ER: Reclassification of odontogenic keratocyst as tumour. Impact on the odontogenic tumours prevalence. Oral Dis 16: 185, 2010.

8. Tawfik MA, Zyada MM: Odontogenic tumors in Dakahlia, Egypt: analysis of 82 cases. Oral Surg Oral Med Oral Pathol Oral Radiol Endod 109: e67, 2010.

9. Sriram G, Shetty RP: Odontogenic tumors: a study of 250 cases in an Indian teaching hospital. Oral Surg Oral Med Oral Pathol Oral Radiol Endod 105: e14, 2008.

10. Varkhede A, Tupkari J-V, Sardar M: Odontogenic tumors: a study of 120 cases in an Indian teaching hospital. Med Oral Patol Oral Cirugia Bucal 16: e895, 2011.

11. Olgac V, Koseoglu BG, Aksakalli N: Odontogenic tumours in Istanbul: 527 cases. Br J Oral Maxillofac Surg 44: 386, 2006.

12. Okada H, Yamamoto H, Tilakaratne WM: Odontogenic tumors in Sri Lanka: analysis of 226 cases. J Oral Maxillofac Surg Off J Am Assoc Oral Maxillofac Surg 65: 875, 2007.

13. Avelar RL, Antunes AA, Santana Santos T de, Souza Andrade ES de, Dourado E: Odontogenic tumors: clinical and pathology study of 238 cases. Braz J Otorhinolaryngol 74: $668,2008$.

14. Luo H-Y, Li T-J: Odontogenic tumors: a study of 1309 cases in a Chinese population. Oral Oncol 45: 706, 2009.

15. Servato JPS, Prieto-Oliveira P, Faria PR de, Loyola AM, Cardoso SV: Odontogenic tumours: 240 cases diagnosed over 31 years at a Brazilian university and a review of international literature. Int J Oral Maxillofac Surg 42: 288, 2013.
16. Ahire MS, Tupkari JV, Chettiankandy TJ, Thakur A, Agrawal RR: Odontogenic tumors: A 35-year retrospective study of 250 cases in an Indian (Maharashtra) teaching institute. Indian J Cancer 55: 265, 2018.

17. Kebede B, Tare D, Bogale B, Alemseged F: Odontogenic tumors in Ethiopia: Eight years retrospective study. BMC Oral Health 17: 54, 2017.

18. Lawal AO, Adisa AO, Olusanya AA: Odontogenic tumours: A review of 266 cases. J Clin Exp Dent 5: e13, 2013.

19. Fernandes AM, Duarte ECB, Pimenta FJGS, Souza LN, Santos VR, Mesquita RA, Aguiar MCF de: Odontogenic tumors: a study of 340 cases in a Brazilian population. $\mathrm{J}$ Oral Pathol Med Off Publ Int Assoc Oral Pathol Am Acad Oral Pathol 34: 583, 2005.

20. Mosqueda-Taylor A, Ledesma-Montes C, Caballero-Sandoval S, Portilla-Robertson J, Ruíz-Godoy Rivera LM, Meneses-García A: Odontogenic tumors in Mexico: a collaborative retrospective study of 349 cases. Oral Surg Oral Med Oral Pathol Oral Radiol Endod 84: 672, 1997.

21. Chidzonga MM, Lopez VM, Alverez AP: Odontogenic tumours: analysis of 148 cases in Zimbabwe. Cent Afr J Med 42: $158,1996$.

22. Ladeinde AL, Ajayi OF, Ogunlewe MO, Adeyemo WL, Arotiba GT, Bamgbose BO, Akinwande JA: Odontogenic tumors: a review of 319 cases in a Nigerian teaching hospital. Oral Surg Oral Med Oral Pathol Oral Radiol Endod 99: 191, 2005.

23. Goteti SH: Odontogenic Tumors: A Review of 675 Cases in Eastern Libya. Niger J Surg Off Publ Niger Surg Res Soc 22: 37, 2016.

24. Adebayo ET, Ajike SO, Adekeye EO: A review of 318 odontogenic tumors in Kaduna, Nigeria. J Oral Maxillofac Surg Off J Am Assoc Oral Maxillofac Surg 63: 811, 2005.

25. Jing W, Xuan M, Lin Y, Wu L, Liu L, Zheng X, Tang W, Qiao J, Tian W: Odontogenic tumours: a retrospective study of 1642 cases in a Chinese population. Int J Oral Maxillofac Surg 36: 20, 2007.

26. Odukoya O: Odontogenic tumors: analysis of 289 Nigerian cases. J Oral Pathol Med Off Publ Int Assoc Oral Pathol Am Acad Oral Pathol 24: 454, 1995.

27. Daley TD, Wysocki GP, Pringle GA: Relative incidence of odontogenic tumors and oral and jaw cysts in a Canadian population. Oral Surg Oral Med Oral Pathol 77: 276, 1994. 
28. Ochsenius G, Ortega A, Godoy L, Peñafiel C, Escobar E: Odontogenic tumors in Chile: a study of 362 cases. J Oral Pathol Med Off Publ Int Assoc Oral Pathol Am Acad Oral Pathol 31: 415, 2002.

29. Resquetti Luppi C, Bin L, Nemer M, Chicarelli da Silva M, Tolentino E, Iwaki L: Odontogenic tumors: Retrospective study of 32 cases diagnosed in a stomatology center in Maringá, Paraná, Brazil. Acta Sci Health Sci 40: 31473, 2018.

30. Osterne RLV, Brito RG de M, Alves APNN, Cavalcante RB, Sousa FB: Odontogenic tumors: a 5-year retrospective study in a Brazilian population and analysis of 3406 cases reported in the literature. Oral Surg Oral Med Oral Pathol Oral Radiol Endod 111: 474, 2011.

31. Regezi JA, Kerr DA, Courtney RM: Odontogenic tumors: analysis of 706 cases. J Oral Surg Am Dent Assoc 1965 36: $771,1978$.

32. Wu PC, Chan KW: A survey of tumours of the jawbones in Hong Kong Chinese: 1963-1982. Br J Oral Maxillofac Surg 23: 92, 1985.

33. Taghavi N, Rajabi M, Mehrdad L, Sajjadi S: A 10-year retrospective study on odontogenic tumors in Iran. Indian J Dent Res Off Publ Indian Soc Dent Res 24: 220, 2013.

34. Johnson NR, Savage NW, Kazoullis S, Batstone MD: A prospective epidemiological study for odontogenic and non-odontogenic lesions of the maxilla and mandible in Queensland. Oral Surg Oral Med Oral Pathol Oral Radiol 115: 515, 2013.

35. Gupta B, Ponniah I: The pattern of odontogenic tumors in a government teaching hospital in the southern Indian state of Tamil Nadu. Oral Surg Oral Med Oral Pathol Oral Radiol Endod 110: e32, 2010.

36. Arotiba JT, Ogunbiyi JO, Obiechina AE: Odontogenic tumours: a 15-year review from Ibadan, Nigeria. Br J Oral Maxillofac Surg 35: 363, 1997.

37. Fregnani ER, Fillipi RZ, Oliveira CRGCM, Vargas PA, Almeida OP: Odontomas and ameloblastomas: variable prevalences around the world? Oral Oncol 38: 807, 2002.

38. Tomizawa M, Otsuka Y, Noda T: Clinical observations of odontomas in Japanese children: 39 cases including one recurrent case. Int J Paediatr Dent 15: 37, 2005.

39. Shafer WG, Hine MK, Levy BM. Cysts and tumours of odontogenic origin. In: Rajendran R, Sivapathasundharam B, editors. A Textbook of Oral Pathology. 6th ed. p. 254309, Delhi: Elsevier; 2009.
40. Philipsen HP, Reichart PA, Praetorius F: Mixed odontogenic tumours and odontomas. Considerations on interrelationship. Review of the literature and presentation of 134 new cases of odontomas. Oral Oncol 33: 86, 1997.

41. Amado Cuesta S, Gargallo Albiol J, Berini Aytés L, Gay Escoda C: Review of 61 cases of odontoma. Presentation of an erupted complex odontoma. Med Oral Organo Of Soc Espanola Med Oral Acad Iberoam Patol Med Bucal 8: $366,2003$.

42. Soluk Tekkesin M, Pehlivan S, Olgac V, Aksakallı N, Alatli $\mathrm{C}$ : Clinical and histopathological investigation of odontomas: review of the literature and presentation of 160 cases. J Oral Maxillofac Surg Off J Am Assoc Oral Maxillofac Surg 70: 1358, 2012.

43. Illa CP, Aytés LB, Sánchez-Garcés MA, Gay-Escoda C: Odontomas complejos y compuestos: Análisis de 47 casos. Arch Odontoestomatol 11: 423, 1995.

44. Wright JM, Soluk Tekkesin M: Odontogenic tumors: where are we in 2017 ? J Istanb Univ Fac Dent 51: S10, 2017.

45. Hidalgo-Sánchez O, Leco-Berrocal MI, MartínezGonzález JM: Metaanalysis of the epidemiology and clinical manifestations of odontomas. Med Oral Patol Oral Cirugia Bucal 13: E730, 2008

46. Oliveira BH de, Campos V, Marçal S: Compound odontoma--diagnosis and treatment: three case reports. Pediatr Dent 23: 151, 2001.

47. White SC, Pharoah MJ. Benign tumours of the jaws. In: White SC, Pharoah MJ, editors. Oral Radiology: Principles and Interpretation. 5th ed. p. 410-58, Missouri: Mosby; 2004.

48. Reichart PA, Philipsen HP, Sonner S: Ameloblastoma: biological profile of 3677 cases. Eur J Cancer B Oral Oncol 31B: 86, 1995.

49. Eversole LR, Leider AS, Nelson K: Ossifying fibroma: a clinicopathologic study of sixty-four cases. Oral Surg Oral Med Oral Pathol 60: 505, 1985.

50. Simon ENM, Merkx MAW, Vuhahula E, Ngassapa D, Stoelinga PJW: A 4-year prospective study on epidemiology and clinicopathological presentation of odontogenic tumors in Tanzania. Oral Surg Oral Med Oral Pathol Oral Radiol Endod 99: 598, 2005.

51. Simon ENM, Merkx MAW, Vuhahula E, Ngassapa D, Stoelinga PJW: Odontogenic myxoma: a clinicopathological study of 33 cases. Int J Oral Maxillofac Surg 33: 333, 2004 . 
52. Monteiro LS, Martins M, Pacheco JJ, Salazar F, Magalhães J, Vescovi P, Meleti M: Er:YAG Laser Assisted Treatment of Central Odontogenic Fibroma of the Mandible. Case Rep Dent 2015: 230297, 2015.

53. Mosqueda-Taylor A, Martinez-Mata G, Carlos-Bregni R, Vargas PA, Toral-Rizo V, Cano-Valdez AM, Palma-Guzman JM, Carrasco-Daza D, Luna-Ortiz K, Ledesma-Montes C, Almeida OP de: Central odontogenic fibroma: new findings and report of a multicentric collaborative study. Web Sci, 2011

54. Tamme T, Soots M, Kulla A, Karu K, Hanstein S-M, Sokk A, Jõeste E, Leibur E: Odontogenic tumours, a collaborative retrospective study of 75 cases covering more than 25 years from Estonia. J Cranio-Maxillo-fac Surg Off Publ Eur Assoc Cranio-Maxillo-fac Surg 32: 161, 2004.

55. Bilodeau EA, Collins BM: Odontogenic Cysts and Neoplasms. Surg Pathol Clin 10: 177, 2017.

56. Badni M, Nagaraja A, Kamath V: Squamous odontogenic tumor: A case report and review of literature. J Oral
Maxillofac Pathol JOMFP 16: 113, 2012.

57. Candido GA, Viana KA, Watanabe S, Vencio EF: Peripheral dentinogenic ghost cell tumor: a case report and review of the literature. Oral Surg Oral Med Oral Pathol Oral Radiol Endod 108: e86, 2009.

58. Philipsen HP, Reichart PA: Adenomatoid odontogenic tumour: facts and figures. Oral Oncol 35: 125, 1999.

59. Philipsen HP, Reichart PA, Siar CH, Ng KH, Lau SH, Zhang X, Dhanuthai K, Swasdison S, Jainkittivong A, Meer S, Jivan V, Altini M, Hazarey V, Ogawa I, Takata T, Taylor AAM, Godoy H, Delgado WA, Carlos-Bregni R, Macias JFR, Matsuzaka K, Sato D, Vargas PA, Adebayo ET: An updated clinical and epidemiological profile of the adenomatoid odontogenic tumour: a collaborative retrospective study. J Oral Pathol Med Off Publ Int Assoc Oral Pathol Am Acad Oral Pathol 36: 383, 2007.

60. Rick GM: Adenomatoid odontogenic tumor. Oral Maxillofac Surg Clin N Am 16: 333, 2004. 